\title{
ANALISIS YURIDIS MONEY POLITIC OLEH CALON ANGGOTA DEWAN PERWAKILAN DAERAH DALAM PEMILIHAN UMUM
}

\author{
Ade Marcelian Pande, Ida Ayu putu Widiati, I Wayan Arthanaya \\ Fakultas Hukum Universitas Warmadewa, Denpasar-Bali, Indonesia \\ Adepande10@gmail.com, Widiati_dayu@yahoo.com, Arthanaya.wayan@gmail.com
}

\begin{abstract}
Abstrak
Money politic merupakan suatu kejahatan terhadap demokrasi yang dicita-citakan oleh negara Indonesia, khususnya terhadap tindak pidana money politic calon anggota dewan perwakilan daerah. Penelitian ini bertujuan mengkaji bentuk-bentuk money politic dalam pemilihan umum dan mengungkapkan sanksi terhadap calon anggota dewan perwakilan daerah yang melakukan money politic. Tipe penelitian yaitu penelitian normatif dengan pendekatan perundang-undangan. Sumber data yang digunakan yaitu data primer dan sekunder. Data dikumpulkan melalui kegiatan membaca, yang dilakukan dengan cara mengumpulkan bahan hukum yang ada atau studi dokumen dari peratuan Perundang-undangan yang ada serta instrument pendukung lainnya. Hasil penelitian menunjukkan bahwa Pengaturan mengenai tindak pidana money politic diatur dalam konstitusi dan beberapa peraturan hukum khusus, bentuk money politic berbentuk uang, berbentuk fasilitas umum, berbentuk sembako, berbentuk proyek.Sanksi yang diterapkan adalah pidana penjara, dan pidana denda atau pidana kurungan pengganti denda. Sanksi pidana diterapkan terhadap pelaku yang memberi maupun menerima segala bentuk money politic. Money politic menjadi strategi untuk memenangkan kontestasi politik.
\end{abstract}

Kata Kunci: Money Politic, Hukum, Pemilihan Umum, Sanksi pidana

\begin{abstract}
Money politics is a crime against democracy as aspired by the Indonesian state, especially against money politics crimes committed by Regional Representative Council Candidates. This study aimed to examine the forms of money politics in general elections and to reveal sanctions against candidates for Regional Representative Council Candidates who committed money politics. This study is normative research with a statutory approach. The sources of data used were primary and secondary data. Data were collected through reading activities, which were carried out by collecting existing legal materials or studying documents from existing laws and regulations and other supporting instruments. The results of the study indicated that the regulation of money politics is regulated in the constitution and some special legal regulations. The form of money politics is in the form of money, public facilities, basic needs, and projects. The sanctions applied are imprisonment and fines or imprisonment instead of fines. Criminal sanctions are applied to perpetrators who gave or received all forms of money politics, which is used as a strategy to win political contestations.
\end{abstract}

Keywords: Money politic, Law, Elections, Criminal sanctions

\section{PENDAHULUAN}

Negara Kesatuan Republik Indonesia yang menjamin hak asasi manusia di dalam hukum sebagaimana diamanatkan dalam konstitusi negara, ini artiannya bahwa setiap warga negara Indonesia dalam terjun dalam dunia pemerintahan (Arifin \& Lestari, 2019). Tetapi dengan mengikuti aliran kebiasaan negara, dimana partai politiklah menjadi sarana masyarakat dalam beraspirasi dan berkesempatan untuk mempunyai kedudukan dalam pemerintahan. Persyaratan mengenai warga negara untuk menjadi calon anggota dewan diatur didalam Undang-undang, dan dengan segala kelengkapan administrasi yang ditentukan juga seseorang mengajukan bakal calon anggota legislatif daerah dapat mengikuti kontestasi politik yang diselenggarakan Komisi Pemilihan Umum (KPU) (Affan, 2015).

Negara Indonesia merupakan negara demokrasi, dalam prinsipnya demokrasi merupakan suatu kedaulatan rakyat (Widodo, 2015). Dengan demokrasi rakyat dapat leluasa menyampaikan aspirasinya terhadap pemerintah dan dijamin oleh konstitusi. Demokrasi yang dianut Indonesia yaitu demokrasi Pancasila, pancasila sebagai filsafat negara memberikan arti bahwa negara Indonesia 
merupakan negara hukum, bukan negara yang otoriter. Demokrasi adalah kunci untuk mewujudkan kedaulatan rakyat. Dengan adanya pengaruh demokrasi, pemerintah sebagai penguasa tidak dapat sewenang-wenang dalam mengambil kebijaksanaannya, tetapi harus diputus berdasarkan musyawarah mufakat (Qomar, 2018). Demokrasi yang lahir dari era reformasi saat ini memiliki cita-cita untuk tercapainya kesejahteraan dan kemakmuran rakyat yang berjalan berdampingan dengan konteks demokrasi dalam bernegara. Wujud dari demokrasi di Indonesia adalah dengan munculnya partai-partai politik yang berlandaskan dan menampung aspirasi seorang warga negara Indonesia dalam bernegara. Pada saat ini, banyaknya partai politik yang bermunculan juga membuat para peserta calon legislatif yang maju dengan melalui partai politik dalam suatu pemilihan umum.

Pemilihan Umum merupakan salah satu instrument yuridis dalam berdemokrasi, saat dimulai pemilihan umum secara langsung pada tahun 2004, hal ini menuai beberapa persoalan yang salah satu diantaranya yang paling menonjol yakni money politic (Pahlevi, 2011). Dengan banyaknya para peserta calon anggota dewan legislatif mempunyai kompetisi yang ketat dan tak heran membuat rakyat bingung (Miriam Budiardjo, 1947:50). Politik uang (money politic) adalah salah satu cara atau bentuk pemberian atau janji yang secara nyata kepada seseorang untuk mendukung calon tertentu dengan menggunakan haknya dalam suatu pemilihan umum secara melawan hukum dan mencederai demokrasi. Dengan demikian maka para calon anggota legislatif akan mendapat dukungan suara pada saat pemilihan umum. Money Politic juga berpotensi membuat perpecahan dalam masyarakat oleh karena kelompok yang terbagi dalam hal dukung-mendukung karena merasa mempunyai rasa balas budi terhadap calon anggtoa legislatif yang didukung. Money politic juga merupakan suatu tindak pidana yang sudah menjadi budaya dalam politik bernegara yang tidak sehat. Berdasarkan permasalahan yang telah dijelaskan sebelumnya, sehingga melakukan penelitian dengan tujuan untuk mengkaji bentuk-bentuk money politic dalam pemilu dan mengungkapkan sanksi terhadap calon anggota dewan perwakilan daerah yang melakukan money politic.

\section{METODE PENELITIAN}

Penelitian ini didesain menggunakan penelitian hukum normatif, dengan pendekatan Perundangundangan. Bahan hukum yang dipakai yakni bahan hukum primer dengan menganalisis dari sumber aslinya Undang-undang. Bahan hukum sekunder yakni bahan hukum berisi mengenai prinsip-prinsip ilmu dari sumber buku-buku, jurnal ilmiah, dan pandangan para ahli yang berkaitan dengan mendukung analisis mengenai money politic oleh calon anggota dewan legistalif daerah. Bahan hukum tersier adalah bahan hukum yang mendukung bahan hukum primer dan sekunder, yang berasal dari Kamus-kamus atau internet. Data diperoleh melalui teknik pengumpulan bahan bacaan, yang dilakukan dengan cara mengumpulkan bahan hukum yang ada atau studi dokumen dari peratuan Perundang-undangan yang ada serta instrument pendukung lainnya. Adapun setelah bahan hukum terkumpul, maka bahan hukum tersebut akan digambarkan dan dijelaskan kalimat perkalimat dengan menggunakan metode pengolahan bahan hukum secara sistematis (Bambang, 2002).

\section{HASIL DAN PEMBAHASAN}

\section{Bentuk-Bentuk Money Politic oleh Calon Anggota Dewan Legislatif Daerah}

Negara Indonesia merupakan negara yang melandasi sistem pemerintahan yang berlandaskan secara demokrasi, dalam sebuah negara demokrasi pemilihan umum merupakan salah satu instrument yuridis sebagai pilar utama dalam memenuhi aspirasi rakyat sebagaimana dalam demokrasi pancasila yang mengutamakan musyawarah dalam menentukan permufakatan untuk menentukan arah keputusan atau kebijakan bersama. Pemilihan Umum diatur dalam Pasal 22E UUD NRI 1945 dan secara khusus dalam Undang-undang (lex specialis), jelaslah bahwa ketentuan mengenai pemilihan umum mempunyai dasar hukum sarana aspirasi masyarakat yang diamanatkan untuk masa depan bangsa terhadap mereka yang terpilih untuk menentukan sikap kebijakan yang diharapkan adalah sebesar-besarnya dapat memanfaatkan sumber daya yang ada untuk kesejahteraan sosial. Oleh karena itu, dalam rangka pelaksanaan hak-hak asasi warga negara adalah keharusan bagi pemerintah untuk menjamin terlaksananya pemilu yang sesuai dengan jadwal ketetanegaraan yang diperlukan (Asshidiqie, 2012).

Politik Uang (Money Politic) adalah salah satu cara atau bentuk pemberian atau janji yang secara nyata kepada seseorang untuk mendukung calon tertentu dengan menggunakan haknya dalam 
suatu pemilihan umum secara melawan hukum dan mencederai demokrasi. Hal ini merupakan suatu kejahatan terhadap demokrasi yang dimana menggerakan seseorang menggunakan haknya dengan bermacam-macam bentuk, tapi mempunyai tujuan adalah untuk meraih suara sebanyaknya dari para simpatisan masayrakat untuk menentukan kemenangan dalam pemilihan umum. Politik uang merupakan suatu sistem tukar menukar pemberian yang dilakukan oleh dua orang atau kelompok yang saling member, dimana pihak penerima akan berusaha mengimbanginya (Suparlan, 1992). Adapun bentuk-bentuk dari money politic, antara lain:

1. Berbentuk Uang (money cash)

Dalam bentuk ini money politic dilakukan dengan cara pemberian uang secara tunai terhadap orang-orang tertentu yang biasanya hadir dalam acara kampanye atau namanya terdapat dalam pencatatan yang dilakukan oleh tim kampanye pendukung calon anggota legislatif tertentu.

2. Berbentuk Fasilitas Umum (Public Facility)

Dalam bentuk ini money politic diberikan dengan cara pendekatan terhadap kelompok masyarakat tertentu dan mengarah pada sasaran utama yang diperlukan masyarakat, contohnya sarana penunjang hobby (lapangan voli, meja pimpong, tenis), tempat keagamaan (musholla, masjid, gereja), jalan atau gang kampung, pendidikan (sekolah, pesantren).

3. Berbentuk Sembako (Consumer Groceries)

Dalam bentuk ini money politic diberikan dalam bentuk bahan baku konsumsi makanan pokok masyarakat langsung, yang pada umumnya diberikan merata terhadap masyarakat didaerah sasaran kampanye. Dapat berupa; beras, gula, minyak goring, mie instan, telur, ikan, dll.

4. Berbentuk Proyek (General Development)

Dalam bentuk ini money politic diberikan khusus terhadap tim sukses apabila telah berhasil memenangkan calon dalam kontestasi politik pemilihan umum, proyek ini berupa jatah pembangunan kecil-kecilan dari pemerintah atau instansi. Contohnya; pembangunan puskesmas, jalan, sekolah.

\section{Sanksi Terhadap Calon Anggota Dewan Perwakilan Dearah yang Melakukan Money Politic}

Tindak pidana pemilihan umum adalah semua tindak pidana dalam aktifitas keikutsertaan dalam pemilihan umum sebagaimana dalam Undang- undang (Santoso, 2001). Seorang yang melakukan tindak pidana haruslah disertai dengan sanksi terhadap perbuatannya itu. Sebelum membahas mengenai penerapan sanksi terhadap pelaku tindak pidana money politic, dalam perkembangan teori pemidanaan dibagi menjadi 3, yakni Absolut atau pembalasan (vergeldings theorien) yaitu pemidanaan ditujukan untuk dasar pembalasan dari perbuatannya; Relatif atau tujuan (doel theorien) yaitu teori ini untuk mengubah pola piker pelaku secara rohani dan jasmani menjadi orang yang lebih baik sehingga diupayakan tidak melakukan sifat tercela dalam masyarakat dan hukum; Gabungan (verenigings theorien) yaitu menitik beratkan pada pembalasan yang disertai dengan ketertiban masyarakat. Selanjutnya sanksi terhadap calon anggota dewan perwakilan daerah terdapat dalam Pasal 265 Undang-undang Nomor 10 Tahun 2008 tentang Pemilihan Umum Anggota Dewan Perwakilan Rakyat, Dewan Perwakilan Daerah, dan Dewan Perwakilan Rakyat Daerah, yang mempunyai unsur-unsur yang harus dipenuhi sebagai meliputi Setiap orang; Dengan sengaja melakukan perbuatan curang; Menyesatkan, memaksa, menjanjikan, memberikan uang atau materi lainnya; Untuk memperoleh dukungan terhadap calon anggota DPD dalam pemilihan umum.

Dengan ancaman sanksi pidana terkait tindak pidana money politic yakni: Pidana Penjara minimal dua belas bulan dan maksimal tiga puluh enam bulan penjara, sedangkan pidana denda paling kecil sebesar Rp. 12.000.000,- (dua belas juta rupiah) dan paling banyak sebesar Rp.36.000.000,- (tiga puluh enam juta rupiah). Pun hal ini juga dapat diterapkan dalam sanksi administrative oleh KPU berupa pembatalan sebagai daftar calon tetap atau pembatalan penetapan sebagai calon terpilih. Hasil pemilihan umum yang diselenggarakan dengan suasana keterbukaan dengan kebebasan berpendapat dan berserikat, dengan hasil yang cermat mencerminkan aspirasi dan partisipasi masyarakat (Budiardjo, 1974). 


\section{KESIMPULAN DAN SARAN}

\section{Kesimpulan}

Dari data yang diperoleh serta hasil analisis data dapat disimpulkan bahwa money politic merupakan sesuatu kejahatan terhadap demokrasi, adapun bentuk-bentuk money politic meliputi berbentuk uang (money cash), berbentuk fasilitas umum, berbentuk sembako atau konsumsi, berbentuk proyek. Sanksi-sanksi terhadap tindak pidana money politic diancam pidana dengan pidana penjara dengan kriteria minimal 12 (dua belas) bulan dan maksimal 36 (tiga puluh enam) bulan penjara, sedangkan pidana denda paling kecil sebesar Rp. 12.000.000, dan paling banyak sebesar Rp.36.000.000. Penerapan sanksi hukum dapat juga diberikan terhadap penerima (masyarakat) yang terbukti menerima praktik money politic dalam pemilihan umum. Dasar huku yang dipakai terdapat dalam Pasal 265 Undang-undang Nomor 10 Tahun 2008 tentang Pemilihan Umum Anggota Dewan Perwakilan Rakyat, Dewan Perwakilan Daerah, dan Dewan Perwakilan Rakyat Daerah.

\section{Saran}

Adapun saran yang dusampaikan peneliti berkaitan dengan simpulan penelitian di atas yaitu bagi partai politik, untuk memenuhi demokrasi di Negara Indonesia perlu adanya penekanan yang dilakukan terhadap semua elemen masyarakat. Partai politik sebagai sarana menjembatani aspirasi masyarakat, diharapkan dapat mebina para calon anggota legislatif daerah untuk dapat mengikuti kontestasi politik dengan baik dan tanpa adanya perbuatan curang untuk terciptanya pola kontestasi politik yang bersih. Dan diharapkan dari proses politik yang bersih adalah calon legislatif adalah sosok yang dapat dipercaya mengemban tugas parlemen legislatif dikedudukan dilegislatif. Bagi masyarakat, peran penting mengenai kesadaran akan money poitik merupakan sesuatu hal yang menentukan untuk kesejahteraan daerah. Untuk itu masyarakat diharapkan lebih mampu untuk dapat menolak, mengantisipasi, serta berani melaporkan segala bentuk yang berkenaan tentang money politik yang ada dilingkungan sekitar.

\section{DAFTAR PUSTAKA}

Affan, S. (2015). Demokrasi, Partai Politik dan Pemilihan Kepala Daerah. Cosmogov, 1(1), 12-24.

Arifin, R., \& Lestari, L. E. (2019). Penegakan dan Perlindungan Hak Asasi Manusia di Indonesia dalam Konteks Implementasi Sila Kemanusiaan yang Adil dan Beradab. Jurnal Komunikasi Hukum, 5(2), 12-25.

Asshidiqie, J. (2012). Pengantar Ilmu Hukum Tata Negara. Raja Grafindo Persada: Jakarta.

Bambang, W. (2002). Penelitian Hukum dalam Praktek. Jakarta: Sinar Grafika.

Budiardjo, M. (1974). Dasar-Dasar Ilmu Politik. Jakarta: Gramedia Pustaka Utama.

Pahlevi, I. (2011). Lembaga Penyelenggara Pemilihan Umum di Indonesia: Berbagai Permasalahannya. Politica, 2(1), 45-72.

Qomar, N. (2018). Hak Asasi Manusia dalam Negara Hukum Demokrasi. Jakarta: Sinar Grafika.

Santoso, T. (2001). lmu Hukum Pidana. Rineka Cipta. Jakarta.

Suparlan, P. (1992). Sasaran Penelitian Antropologi. Raja Grafindo Persada: Jakarta.

Widodo, E. T. (2015). Negara Hukum, Konstitusi, dan Demokrasi. University Press. Jember. 